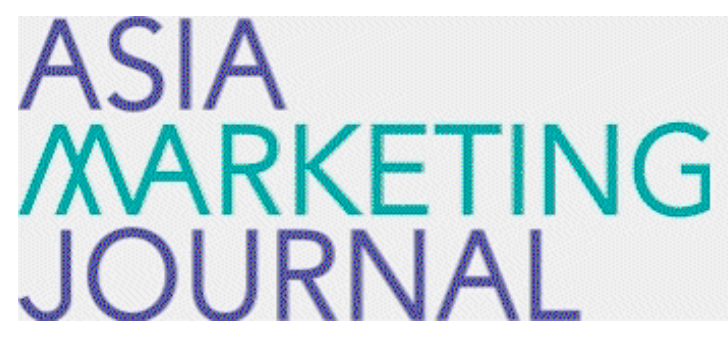

ASIA MARKETING JOURNAL

Volume 19 | Issue 4

Article 4

$1-31-2018$

\title{
Examining Decision-Making of Participating in Open Innovation Platform
}

Insoo Son

Jong-Ho Lee

Dongwon Lee

Follow this and additional works at: https://amj.kma.re.kr/journal

Part of the Marketing Commons

\section{Recommended Citation}

Son, Insoo; Lee, Jong-Ho; and Lee, Dongwon (2018) "Examining Decision-Making of Participating in Open Innovation Platform," Asia Marketing Journal: Vol. 19 : Iss. 4 , Article 4.

Available at: https://doi.org/10.15830/amj.2018.19.4.61

This Article is brought to you for free and open access by Asia Marketing Journal. It has been accepted for inclusion in Asia Marketing Journal by an authorized editor of Asia Marketing Journal. 


\title{
Examining Decision-Making of Participating in Open Innovation Platform: The Case of Biotechnology Industry
}

\author{
Insoo Son* \\ Jong-Ho Lee** \\ Dongwon Lee Le** $^{* * 2}$
}

\begin{abstract}
Open innovation is based on a different knowledge landscape, with a different logic about the sources and uses of technologies. It implies that firms increasingly rely on external sources of innovation by emphasizing these ideas and resources. Using datasets from the UK biotechnology industry, this paper explores firms' willingness to participate in open innovation. The results indicate that the switching cost is identified as the direct predictor of the willingness to participate in open innovation. While high commitment based on the trust with partner increases switching costs, IT infrastructure within the firm decreases switching costs to open innovation. Taken together, this research broadens the study on open innovation by applying the switching cost as a medium of knowledge transfer in the biotech industry.
\end{abstract}

Key words: biotechnology industry, IT infrastructure, open innovation, switching cost, trust

\section{Introduction}

High-technology firms increasingly reach beyond their organizational boundaries and partner with others to develop successful new products in a timely fashion (Boudreau et al.
1998; Kim et al. 2017). New product development in recent years is often a result of a jointly managed activity within a strategic alliance of two or more firms (Doz and Hamel 1998; Osborn et al. 1990; Pavlou and El Sway 2006). Reducing innovation cycles through the use of information technologies also amplifies the importance of

Ph.D. Assistant Professor Department of Global Business Administration Sangmyung University (insoo114@smu.ac.kr)

** Ph.D. Professor of Marketing Korea University Business School (jongholee@korea.ac.kr), Corresponding Author

*** Ph.D. Professor of MIS Korea University Business School (mislee@korea.ac.kr) 
rich information exchange with suppliers in new product development activities (Hult et al. 2002; Pavlou and El Sway 2006). It even appears that inter-organizational cooperation around innovations has become an imperative these days (Boudreau et al. 1998; Gularti and Singh 1998; Newell and Swan 2000). Driven by this recognition of the role of external knowledge in innovation, it has been argued that innovation is undergoing with a paradigm shift from 'closed' to 'open' models (Chesbrough 2003; Christensen et al. 2005; von Krogh and von Hippel 2006). In line with this, open innovation - innovation practices through open platform for knowledge sharing (Dahlander and Gann 2010) has become central in discussion about its use and expected values among both researchers and practitioners.

Open innovation is based on a different knowledge landscape with a different logic about the sources and uses of technologies. The emergence of open innovation implies that firms increasingly rely on external sources of innovation to secure their competitive edges in the market (Chesbrough 2003). Previous studies argue that firms' innovative capabilities as well as competitive advantages can be significantly improved by leveraging the skills of others through the transfer of knowledge (Cavusgil et al. 2003; Pavlou and El Sway 2006). Network scholars studying cross-functional knowledge sharing find a positive relationship between active mutual knowledge sharing and organizational performance (Atuahene-Gima and Evangelista 2000; Roberts et al. 2006). Thus, close relationship between partner firms has a positive effect on tacit knowledge transfer and subsequently on innovation capability and performance (Cavusgil et al. 2003).

Since Chesbrough (2003)'s breakthrough research, there have been numerous studies on open innovation. Major research streams in extant literature include searching and enabling external innovations (e.g., Ili et al. 2010; Tether and Tajar 2008), assimilating external sources of innovations (e.g., Fabrizio 2009; Schiele 2010), and value creating role of open innovation (e.g., Boudreau 2010; Lau et al. 2010). Researchers suggest that not only the characteristics of external knowledge but internal factors such as R\&D capabilities and complementary assets also influence the use of external sources of innovation (Ceccagnoli et al. 2010; Teirlinck et al. 2010). Furthermore, the rise of Internet has played an important role in enabling open innovation by facilitating online communities, crowd sourcing, and virtual world (Ebner et al. 2009; Füller et al. 2008; Kohler et al. 2009). Another research stream argues that firms need to integrate external sources with their R\&D activities and organizational culture to fully profit from open innovation (Schiele 2010; Un 2010). In line with this, prior studies emphasize the facilitating role of absorptive capacity in adopting open innovation, such as speeding the assimilation 
and commercialization of external knowledge (Fabrizio 2009; Grimpe and Sofka 2009). Open innovation scholars also have sought to quantify the benefits of external innovations in terms of innovation output and financial performance. The studies used standard metrics including new product release (Boudreau 2010), product performance (Lau et al. 2010), revenue growth (Chesbrough and Crowther 2006), and the fraction of revenues due to new products (Grimpe and Sofka 2009). Value creation was also examined in the few simulation-based studies on external sources of innovation (e.g., Almirall and Casadesus-Masanell 2010).

Prior studies in this stream of research contribute to the extant literature by expanding our understanding of open innovation in the aspects of obtaining, integrating, and commercializing the sources of external innovation. However, there has been limited attention to identify the enabling factors and examining how these antecedents affect firms' organizational decision to participate in open innovation platform. In recent years, the really good ideas are coming from outside the organization especially in the biotech industry (Powell 1998). The availability and quality of external ideas change the logic that leads to the formation of the centralized R\&D in closed innovation (Christensen et al. 2005). The open innovation idea has become influential in biotech firm strategies, and it is therefore timely to examine adaptability of the open innovation approach. To this end, the study explores organizational decision-making mechanism to participate in open innovation from ongoing closed alliances in the virtual laboratory context in the biotechnology.

As an exploratory study on organizational adoption of open innovation, this study intends to investigate what factors affect firms' open innovation initiatives. Especially, our research focuses on the effect of switching cost on firms' willingness to participate in open innovation platform. Initiating open innovation implies a shift of firms' $R \& D$ and innovation paradigm. Each firm needs to evaluate the performance of alliances with existing partners by comparing with the expected value of open innovation. Switching cost is a main construct to measure how much burden firms recognize when transferring their innovation paradigm from closed to open environment. The level of involving switching cost in open innovation adoption depends on how well the collaboration with existing partners has been maintained based on mutual trust. In this sense, commitmenttrust constructs are required to measure the performance of current partnership for innovation and connected to the engagement of switching cost in organizational adoption of open innovation. IT infrastructure, in this study, is a contextual factor related with virtual laboratory, a practical example of open innovation in biotechnology. Open innovation is a worldwide network of organizations with different knowledge and business backgrounds and operates on IT based 
communications like Internet. The level of a firm's IT infrastructure (e.g., IT resources and management skill) is another significant prerequisite of initiating open innovation. This study argues the role of IT infrastructure in reducing the burden of open innovation and increasing the willingness to participate. Putting all together these switching cost, commitmenttrust, and IT infrastructure constructs, we suggest a research model to explain organizational adoption of open innovation.

The remainder of the paper is organized as follows. We first present, in Section 2, the theoretical background of open innovation and a formal basis for a set of hypotheses to examine a firm's willingness to participate in open innovation, based on a number of different concepts including commitment-trust, IT infrastructure, and switching costs. The third section provides the research methodology along with the description of data and instrument validation. The fourth section describes our empirical findings. (1) Switching costs hinder participation in open innovation. While (2) commitment based on the trust with partner increases switching costs, (3) IT infrastructure within the firm decreases switching costs for open innovation. The fifth section concludes with a discussion on a number of implications for research and practice, as well as the limitations and possible extensions for future research.

\section{Theoretical Framework}

The primary objective of this paper is to explore the question of how open innovation is applied to the research and development (R\&D) in the virtual laboratory of the biotech industry. For example, how biotech scientists in different organizations can share or transfer their knowledge efficiently? Open innovation is a new manner of working for new product development. It provides an experimental setting to scientists and engineers by making optimal use of information technologies.

\subsection{Open Innovation and Biotechnology Industry}

Open innovation is a term coined by Chesbrough (2003), and its main idea is that firms cannot afford to rely entirely on their own research, but should instead buy or license processes or inventions from other organizations (Chesbrough 2003; Christensen et al. 2005). Although there exists similarity in names between open source and open innovation, they have different perspectives in new product developmentthat is, open innovation emphasizes patenting and selling inventions while open source stresses sharing of programming codes or computer programs. In knowledge sharing perspective, open innovation has two-sided features; 1) providing a firm's internal know-hows to other 
organizations and 2) receiving external knowledge from outside. Under such conditions, firms need to configure how much they should release their own knowledge to acquire as much knowledge as they want to achieve the optimal point of mutual benefit. But, firms occasionally have contradictory attitudes toward this 'give-andtake' features and show opportunistic behaviors like providing less and receiving more.

The nature of the biotech industry, which shares knowledge and ideas through many forms of collaborations and strategic alliances, indeed facilitates the use of open innovation (Powell 1998). In practice, the adoption and use of open innovation in the biotech industry can be divided into two stages - first, the manipulation and search of a vast amount of data; and second, data-sharing and productdevelopment (Mangalam et al. 2001). In this light, when it comes to the biotech industry, the following question must be raised: what factors lead firms in the biotech industry to adopt the open innovation approach to develop new products or drugs? Firms are often motivated to make strategic alliances for new product development (Kogut 1988), with the types of alliance governance structures, such as joint ventures and non-equity alliances, determined by the following factors: (1) interdependence and knowledge transfer (Doz and Hamel 1998), (2) control mechanisms (Gulati and Singh 1998), and (3) flexibility (Das and Teng 2002).

The biotech industry has been actively involved in networking and strategic alliances with other companies and academic organizations and, as a result, understands the needs for a more open way of working and collaboration as well as their pitfalls (Powell 1998). To access the expertise of others, firms often employ social capital, an idea linked to technology brokering, an activity of technology brokers who gain access to external ideas for internal use for the purpose of innovation (Kankanhalli et al. 2005; Wasko and Faraj 2005). In this sense, the networks in the biotech industry through social capital can be identified as primary sources of technological as well as organizational innovations (Staropoli 1998). Despite the benefits of networking, however, there is a considerable risk associated with the level of knowledge to share within the network due to the relatively uncontrollable spread of knowledge and/or uncertain results (Jarvenpaa et al. 2004; Stewart and Gosain 2006). Firms' characteristics as either 'risk-taking' or 'risk-averse' may affect the level of knowledge they share in open innovation. How scientists in different countries can share their knowledge efficiently? Virtual laboratory is an IT-enabled platform in which biotechnology experiments are planned, designed, and performed through the collaboration with scientists and engineers from participating firms. It provides an experimental setting to scientists and engineers by making optimal use of modern information technologies. Virtual laboratory is a new manner of working in that 
it provides the worldwide pool of industry expertise for R\&D and innovation beyond physical locations and boundaries. For biotechnology industry, virtual laboratory presents conceptual features shared with open innovation. Virtual laboratory operates based on firms' voluntary participation and pursues mutual benefit of participants by sharing knowledge and expertise. Additionally, virtual laboratory is open to wide range of biotechnology stakeholders from research to business. Considering the features, it is worth noting that virtual laboratory is a representative example of open innovation in biotechnology industry and used as an equivalent term of open innovation in this paper.

This study has identified three main constructs -commitment-trust, IT infrastructure, and switching costs - as important factors that influence the adoption of open innovation as a medium of knowledge sharing. So, we propose a model in which firms' willingness to participate in open innovation are hypothesized to be affected by such factors as (1) the level of commitment-trust of participating firms, (2) the level of IT infrastructure of participating firms, and (3) the switching cost to open innovation from ongoing closed alliances. Figure 1 presents the theoretical model of our proposed hypotheses with several control variables. We describe each of the constructs and their relationships to the dependent variables in the following sections.

\subsection{Commitment and Trust}

For firms to establish ties with other business

〈Figure 1〉 Theoretical Model of Open Innovation (OI)

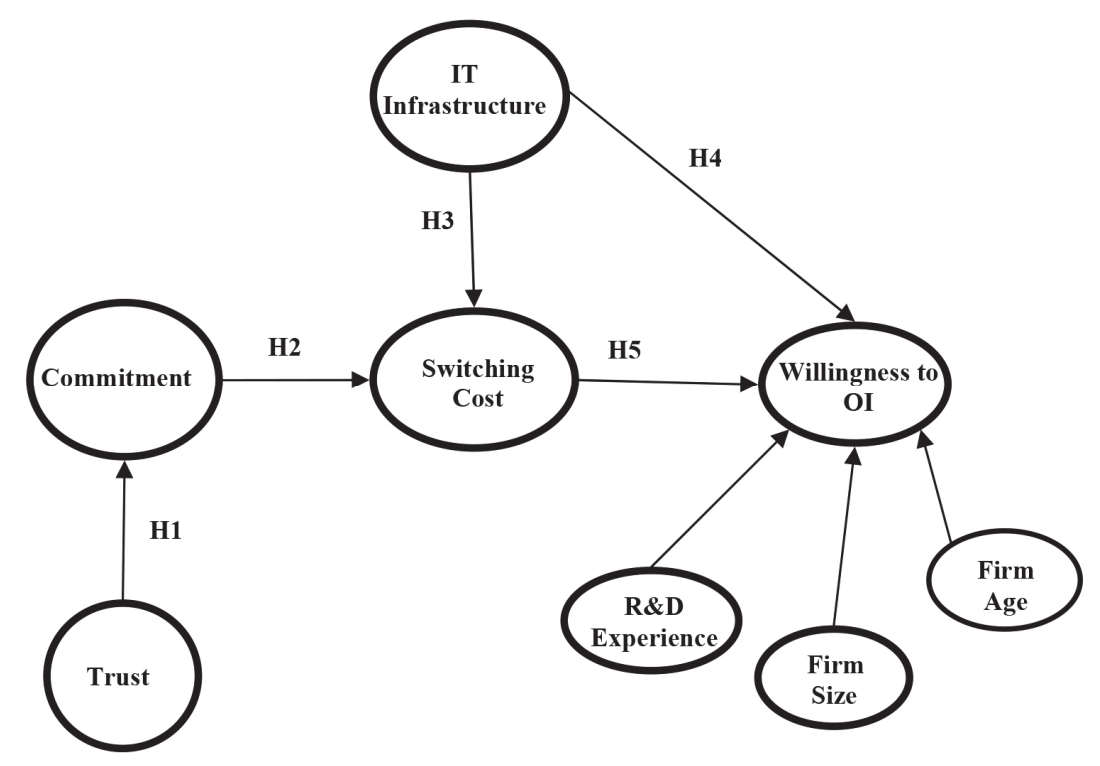

66 ASIA MARKETING JOURNAL Vol. 19 No. 04 January 2018 
partners or share their expertise or knowledge (i.e. the adoption of open innovation), there must exist commitment and trust between existing or potential R\&D partners. Literature on organizational commitment and trust theory hypothesizes that commitment and trust are relatively stable attributes, which act as a reliable link between firms' attitudes and behaviors (Angle and Perry 1981; Koch and Steers 1978; Porter et al. 1974). Firms would not abruptly discontinue their relationships with existing trading partners if they have worked to build a long-term relationship based on their commitment and trust toward each other. In other words, firms with a strong sense of commitment and trust toward their exchange partners would hesitate to pursue short-term alternatives, however attractive they are, in favor of the expected long-term benefits of staying with existing partners (Morgan and Hunt 1994). In this sense, developing and maintaining long-term relationships act as an effective control mechanism (Doney and Cannon 1997; Dwyer et al. 1987; Morgan and Hunt 1994; Wilson 1995). Dwyer et al. (1987) argue that building trust between exchange partners is positively related with a higher likelihood of cooperative relationships and therefore place commitment at the most advanced and stable stage of buyer-seller relationships.

Trust, in particular, contributes to reducing transactional uncertainty through previous collaborative experiences with the third parties and an expectation toward trusted parties (Doney and Cannon 1997). Trust, in addition, facilitates firms to establish inter-organizational networks as a means to overcome SME (Small and Medium Enterprise) isolation (Newell and Swan 2000). Newell and Swan (2000) identify three types of trust: 1) companion trust based on judgments of goodwill or personal friendship, 2) competence trust based on the perception of competence to carry out certain tasks, and 3) commitment trust, for example, contractual agreements. Such different dimensions of trust shape the inter-organizational relationships in a specific network (Ring and van de Ven 1994). Ganesan (1994) argues that trust fosters long-term orientation between exchange partners by shifting the focus to future conditions. Morgan and Hunt (1994) empirically demonstrate that strong trust decreases propensity to leave, the perceived likelihood that a partner will terminate the relationship in the near future. Anderson and Weitz (1989) also report that the strong feeling of trust between exchange partners increases the channel partners' perception of the likelihood that the relationship will continue. Therefore, trust positively influences the longevity of exchange relationship.

Therefore, when a firm has a strong belief on its exchange partner's credibility and benevolent nature, it would desire to stay with the partner as long as possible even when there are economically better exchange relationships available. Therefore, we suggest the following 
hypothesis to examine the relationship between trust and the commitment:

\section{Hypothesis 1 (The Trust-Commitment} Hypothesis): There is a positive relationship between trust with existing research partners and commitment to them.

Commitment has been considered as an important element for sustaining long-term buyer-seller relationships (Morgan and Hunt 1994) as well as for successful information systems (IS) development in IS projects (Newman and Sabherwal 1996). Dwyer et al. (1987, p. 19) define commitment as "an implicit or explicit pledge of relational continuity between exchange partners." Moorman et al. (1992) characterize commitment as an enduring desire to maintain a valued relationship. Anderson and Weitz (1992, p. 19) define commitment as "a desire to develop a stable relationship, a willingness to make short-term sacrifices to maintain the relationship, and a confidence in the stability of the relationship." Morgan and Hunt (1994) describe relationship commitment as an exchange partner believing that an ongoing relationship with another is so important as to warrant maximum efforts at maintaining it.

These definitions or characterizations of commitment suggest that commitment acts as a foundation for forming lasting attitudes and future intention for the continuation of valued exchange relationships. Companies with strong commitment toward current exchange partners are shown to have a strong long-term orientation (Dwyer et al. 1987) and a lower propensity to leave the relationship (Morgan and Hunt 1994). A firm with a strong sense of commitment with existing technology sharing partners will have less tendency to stop their current relationships because overall quality of the current relationship is satisfactory and provides less motivation to find alternatives for replacement (Chen and Forman 2006; Das and Teng 2002). As the current relationship remains longer, interdependency among partners could be increased. The increased interdependency makes it harder to switch over to other alliances or partnerships and consequently lead to higher switching costs. Based on the above theoretical arguments, we propose the following hypothesis on the relationship between commitment and the switching costs:

\section{Hypothesis 2 (The Commitment-Switching} Cost Hypothesis): There is a positive relationship between the commitment to existing research partners and the switching costs.

\subsection{IT Infrastructure}

A number of studies on organizational innovation and technology adoption suggest the characteristics of internal resources such as knowledge depth in technology (Ross et al. 1996: Weill and Broadbent 1998), and absorptive 
capacity (Boynton et al. 1994; Cohen and Levinthal 1990) as influencing factors for the adoption of innovation. The concept of internal resources encompasses intangible knowledge resources as well as tangible assets such as existing equipment (Cavusgil et al. 2003; Wasko and Faraj 2005).

Previous studies show that internal resources promote the adoption of innovation (Rogers 1995). Existing knowledge and internal resources can improve the speed of learning about new technology and lower the amount of extra investment to adopt the technology (Kim and Wilemon 2014). A firm's IT infrastructure has been considered as a major business resource and a key factor for achieving long-term competitive advantages (Ross et al. 1996; Weill and Broadbent 1998).

This study examines the effect of IT infrastructure as an internal resource on the prospects of open innovation. The term IT infrastructure represents the following: (1) the availability of telecommunication infrastructure within the company, (2) the usage of databaseoriented applications in daily operations of the company, and (3) the availability of the integrated information system to encompass different functional areas (Ross et al. 1996; Weill and Broadbent 1998). These are all related to the speed and efficiency with which internal information is transferred across the company and especially to those within the firm that make decisions of technology adoption
(Bharadwaj 2000; Sambamurthy et al. 2003). In this sense, IT infrastructure can be considered to represent absorptive capacity, a term introduced by Cohen and Levinthal (1990, p. 128), defined as the ability to recognize the value of new information, assimilate it, and apply externally generated knowledge. In high technology industries, firms with a high level of IT infrastructure may be more proactive and readily exploit emerging new technologies and market opportunities including open innovation opportunities, since they have already realized that being open to new opportunities greatly enhance firms' ability for further technological advances. With these ideas in mind, we present the following two hypotheses to examine the role of IT infrastructure on the switching cost and the adoption of open innovation:

Hypothesis 3 (The IT Infrastructure-Switching Costs Hypothesis): There is a negative relationship between IT infrastructure and the switching costs.

Hypothesis 4 (The IT Infrastructure-Open Innovation Hypothesis): There is a positive relationship between IT infrastructure and the willingness to participate in open innovation.

\subsection{Switching Costs}

According to the social exchange theory, exchange partners will be motivated either to 
maintain their existing exchange relationships or to seek other transaction partners, depending on the quality of the outcomes from past, present or alternative relationships (Das and Teng 2002: Schurr and Ozanne 1985). However, Kelly and Thibaut (1978) suggest an exception to this rule - an individual may remain in the present, less rewarding relationships if the social, emotional, or legal costs that are entailed in moving to the better alternatives are too high.

Switching from existing channel relationships to new ones causes switching costs that act as a disincentive to pursue new suppliers (Chen and Forman 2006; Heide and Weiss 1995). When expected switching costs are high, firms have stronger desire to maintain currently beneficial relationships and are less likely to replace existing channel relationships with new ones (Dwyer et al. 1987; Weiss and Anderson 1992). Chen and Forman (2006) find that switching costs can lead to inefficient adoption of new technologies (e.g., network switches and routers) in long-term market structures. So, firms are forced to stay with existing relationships to defray high switching costs, however strong the impetus to change is (Weiss and Anderson 1992).

This would be especially the case with the firms in the biotech industry that are faced with the decision of adopting open innovation because switching their collaboration from an off-line real laboratory to an on-line virtual laboratory (i.e., open innovation) can incur a great deal of associated costs compared with establishing relationships, including search costs, costs for drafting detailed contracts, and monitoring costs. All else being equal, firms will be motivated to stay in existing relationships to avoid the impact of switching costs. Therefore, we present the following hypothesis on the relationship between switching costs and the adoption of open innovation:

Hypothesis 5 (The Switching Costs-Open Innovation Hypothesis): There is a negative relationship between switching costs and the willingness to participate in open innovation.

\section{Research Method}

To examine the proposed research model, we adopted the survey method for data collection, and tested our hypotheses by applying the partial least square (PLS) method to the collected data.

\subsection{Semi-Structured Interview}

Previous studies provided useful information and findings on the attributes of strategic alliances (e.g. Das and Teng 2002; Gulati and Singh 1998; Osborn et al. 1990). However, because those studies were not specifically addressed to strategic alliances or collaborations 
in the form of open innovation in the biotech industry, interviews with managers of biotech firms were carried out for more direct information on the prospects of open innovation within the industry. The target population was Biotech CEOs (chief executive officers) and CSOs (chief scientific officers) who were believed to have a good understanding of their technological assets and strategies. Five senior practitioners (i.e., 3 CEOs and 2 CSOs) from biotech firms in the UK participated in the interviews to develop a questionnaire related to open innovation in the biotech industry.

The interviews began with a series of open questions. Interviewees were encouraged to freely express their opinions on the topics related to open innovation, the strengths and weaknesses of open innovation, and the factors leading to the success in R\&D alliances and difficulties of alliances. In the second part of the interview, a list of suggested factors that may be important in the decision to participate in open innovation was distributed to the interviewees. The list was designed on the Likert scale and the interviewees were asked to rate the factors from 1 (strongly disagree) to 7 (strongly agree). The topics covered included specific factors of commitment, trust, power exercised, outcome of alliance, IT infrastructure, switching costs, uncertainty, technology opportunism, security, and the relative advantage of open innovation. The results from the interviews indicated that commitment-trust, IT infrastructure, and switching costs were the most important factors in making a decision for open innovation. The interview results confirmed and refined the five hypotheses developed for this study from the literature and additional findings.

\subsection{Survey Administration}

Data were collected through a mail survey. 123 UK biotech firms, actively involved in the drug development, were randomly selected from the bio-partner UK web site (www.biopartner. co.uk). From 123 questionnaires sent, 48 responses (from $30 \mathrm{CEOs}$ and $18 \mathrm{CSOs}$ ) were received, reaching a response rate of $39 \%$. Pretesting of the questionnaire was undertaken with three CEOs and three CSOs from six biotech firms. Some questions were edited. The questionnaire began with a brief statement of the purpose of the survey and a brief introduction of virtual laboratory as the context of open innovation. The questionnaire was divided into five parts, covering the main hypotheses: (1) previous alliance experience; (2) commitment and trust; (3) IT infrastructure within the organization; (4) switching costs to open innovation; and (5) company and personal information. The questionnaire was distributed by mail with a cover letter and a pre-paid return envelope. Some questions were asked in a reversed way to check respondents' consistency in their answers. In order to obtain the responses from both CEOs and CSOs, recipients were controlled from the 
〈Table 1〉 Demographic Information of Companies and Respondents

\begin{tabular}{|c|c|c|c|c|c|c|c|}
\hline \multicolumn{8}{|c|}{ (a) Company Profile } \\
\hline Measure & Items & Freq. & Percent & Measure & Items & Freq. & Percent \\
\hline $\begin{array}{c}\text { Company } \\
\text { Age }\end{array}$ & $\begin{array}{l}2 \sim 3 \text { yrs } \\
4 \sim 6 \text { yrs } \\
7 \sim 8 \text { yrs } \\
9 \sim 10 \mathrm{yrs}\end{array}$ & $\begin{array}{r}21 \\
11 \\
10 \\
6\end{array}$ & $\begin{array}{l}43.8 \\
22.9 \\
20.8 \\
12.5\end{array}$ & $\begin{array}{l}\text { Number of } \\
\text { Licensing }\end{array}$ & $\begin{array}{c}0 \\
1 \sim 3 \\
4 \sim 8 \\
9 \sim 12\end{array}$ & $\begin{array}{r}8 \\
25 \\
10 \\
5\end{array}$ & $\begin{array}{l}16.7 \\
52.1 \\
20.8 \\
10.4\end{array}$ \\
\hline $\begin{array}{l}\text { Number of } \\
\text { Employees }\end{array}$ & $\begin{array}{c}4 \sim 5 \\
6 \sim 8 \\
9 \sim 11 \\
12 \sim 14\end{array}$ & $\begin{array}{r}12 \\
20 \\
14 \\
2\end{array}$ & $\begin{array}{r}25.0 \\
41.7 \\
29.2 \\
4.2\end{array}$ & $\begin{array}{c}\text { Number of } \\
\text { Patents }\end{array}$ & $\begin{array}{c}0 \\
1 \sim 2 \\
3 \sim 4 \\
5 \sim 8\end{array}$ & $\begin{array}{r}12 \\
17 \\
16 \\
3\end{array}$ & $\begin{array}{r}25.0 \\
35.4 \\
33.3 \\
6.3 \\
\end{array}$ \\
\hline $\begin{array}{l}\text { Number of } \\
\text { R\&D Alliance } \\
\text { Experience }\end{array}$ & $\begin{array}{c}0 \\
1 \sim 2 \\
3 \sim 5 \\
6 \sim 7 \\
8 \sim 10\end{array}$ & $\begin{array}{r}7 \\
11 \\
21 \\
5 \\
4\end{array}$ & $\begin{array}{r}14.6 \\
22.9 \\
43.8 \\
10.4 \\
8.3\end{array}$ & $\begin{array}{l}\text { Number of } \\
\text { Products in } \\
\text { Development }\end{array}$ & $\begin{array}{l}0 \\
1 \sim 2 \\
3 \sim 5 \\
6 \sim 7\end{array}$ & $\begin{array}{r}8 \\
21 \\
13 \\
6\end{array}$ & $\begin{array}{l}16.7 \\
43.8 \\
27.1 \\
12.5\end{array}$ \\
\hline \multicolumn{8}{|c|}{ (b) Respondent Demographics } \\
\hline Measure & Items & Freq. & Percent & Measure & Items & Freq. & Percent \\
\hline Age & $\begin{array}{c}30 \sim 39 \\
40 \sim 49 \\
50 \sim\end{array}$ & $\begin{array}{l}11 \\
26 \\
11\end{array}$ & $\begin{array}{l}22.9 \\
54.2 \\
22.9\end{array}$ & $\begin{array}{l}\text { Work } \\
\text { Experience } \\
\text { (in years) }\end{array}$ & $\begin{array}{c}0 \sim 5 \\
6 \sim 10\end{array}$ & $\begin{array}{l}32 \\
16\end{array}$ & $\begin{array}{l}66.7 \\
33.3\end{array}$ \\
\hline Position & $\begin{array}{l}\mathrm{CEO} \\
\mathrm{CSO}\end{array}$ & $\begin{array}{l}30 \\
18\end{array}$ & $\begin{array}{l}62.5 \\
37.5\end{array}$ & $\begin{array}{l}\text { Bio-related } \\
\text { Degree }\end{array}$ & $\begin{array}{l}\text { Yes } \\
\text { No }\end{array}$ & $\begin{array}{r}48 \\
0\end{array}$ & $\begin{array}{r}100.0 \\
0.0\end{array}$ \\
\hline
\end{tabular}

selected company list. Table 1 reports the respondents' characteristics and firm information.

\subsection{Operationalization of Constructs}

We operationalized prospects on open innovation in two ways. For participants with no alliance experience, two factors were introduced: IT infrastructure within a firm and expected switching costs to open innovation. For firms that had already participated in R\&D alliances, questions related to commitment and trust as well as IT infrastructure and switching costs were included in the questionnaire to examine the effects of cooperation backgrounds on the prospects of open innovation.

To measure the level of commitment of firms to their alliance partners, this research adopted Anderson and Weitz's (1992) scale. To measure trust, three items were selected from Doney and Cannon's (1997) scale. They argue that the two dimensions of trust, credibility and benevolence, are operationally inseparable in practice due to high correlations between them. They treat trust as a unidimensional construct and find very high reliability ( $\alpha=$ 
.94) on the scale for trust. In measuring IT infrastructure, Premkumar and Ramamurthy's (1995) scale was used, along with some consideration about the degree of personal usage. To measure switching costs, three items were selected from Weiss and Anderson's (1992) scale. For the dependent variable, i.e., the willingness to participate in open innovation, we used the behavioral intention scale, adapted from Fishbein and Ajzen (1975), including knowledge openness and the level of willingness to participate in open innovation. To examine the effects of R\&D alliance experience on firms' prospects toward open innovation, the number of R\&D alliances was used as a control variable. The number of $R \& D$ alliances quantifies the R\&D alliance experience and implies how actively a firm has been in collaboration with other firms. In addition, to control firm size, the number of employees and company age were used. All measures for each construct with summary statistics for the variables used in this study are shown in Table 2.

〈Table 2〉 Summary of Multi-Items and Summary Statistics

\begin{tabular}{|c|c|c|c|}
\hline Constructs & Summary of Multi-Items & Mean & St. dev. \\
\hline \multirow{3}{*}{ Commitment } & CO1: We have a sense of loyalty to research partners & 5.39 & (771 \\
\hline & $\begin{array}{l}\text { CO2: The relationships with our research partners are long-term } \\
\text { alliances }\end{array}$ & 4.95 & 1.094 \\
\hline & CO3: We are willing to make long-term investments in the alliance & 5.32 & .960 \\
\hline \multirow{3}{*}{ Trust } & TR1: We find it necessary to be cautious with our research partners ${ }^{(\mathrm{R})}$ & 5.20 & .601 \\
\hline & TR2: Our research partners keep our best interests in mind & 5.00 & .632 \\
\hline & TR3: Our research partners are trustworthy & 5.59 & .591 \\
\hline \multirow{3}{*}{$\begin{array}{l}\mathrm{IT} \\
\text { Infrastructure }\end{array}$} & IT1: Database-oriented applications are regularly used in daily operations & 4.46 & 1.719 \\
\hline & IT2: Integrated IS applications encompass different functional areas & 3.63 & 1.771 \\
\hline & IT3: Telecommunication infrastructure is available in our company & 4.17 & 1.263 \\
\hline \multirow{3}{*}{$\begin{array}{l}\text { Switching } \\
\text { Costs }\end{array}$} & SC1: Participating in open innovation would not be expensive for us ${ }^{(\mathrm{R})}$ & 3.76 & .943 \\
\hline & SC2: It is costly to join open innovation & 3.93 & 1.034 \\
\hline & SC3: We face barriers to switch over to open innovation & 3.71 & 1.055 \\
\hline Experience & EX: Number of R\&D alliances so far including current alliance(s) & 4.02 & 2.286 \\
\hline Firm Size & FS: Number of employees & 7.44 & 2.500 \\
\hline Firm Age & FA: Number of years since the establishment of the firm & 5.46 & 2.56 \\
\hline \multirow{2}{*}{$\begin{array}{l}\text { Willingness } \\
\text { to OI }\end{array}$} & $\begin{array}{l}\text { OI1: We are going to open our technical know-how to any companies } \\
\text { in open innovation }\end{array}$ & 3.02 & 1.405 \\
\hline & OI2: Our company is going to participate in open innovation & 3.59 & 1.643 \\
\hline
\end{tabular}

Note. ${ }^{(\mathrm{R})}$ indicates that item was reverse-worded. 


\subsection{Validating Instruments}

We used PLS to validate the proposed model and examine our hypotheses. PLS requires minimal demands on sample size (Chin, 1998) and is suitable for assessing theories in the early stages of development (Fornell and Bookstein, 1982) just as in our study. More specifically, PLS-Graph Version 3.00 was used for our analysis. Confirmatory factor analysis (CFA) was first conducted to assess the measurement model, and then the structural relationships were examined.

To validate our measurement model, we assessed three types of validity-content validity, convergent validity, and discriminant validity. Content validity was established by ensuring consistency between the measurement items and the extant literature. In addition, we applied Cronbach's alpha test to the individual scales and the overall measures to assess internal consistency. As reported in Table 3, the Cronbach's alpha values ranged from 7169 (for trust) to .8524 (for willingness to open innovation), which are over the threshold of .7 (Nunally and Bernstein, 1994). We also assessed convergent validity by examining composite reliability and average variance extracted (AVE) from the measures (Hair et al. 1998). Although a number of studies using PLS applied .5 as the threshold reliability of the measures, .7 is a recommended value for a reliable construct

〈Table 3〉 Results of Confirmatory Factor Analysis

\begin{tabular}{|c|c|c|c|c|c|}
\hline Constructs & Items & Loading & $\begin{array}{l}\text { Composite } \\
\text { Reliability }\end{array}$ & $\mathrm{AVE}^{*}$ & $\begin{array}{c}\text { Cronbach's } \\
\text { Alpha }\end{array}$ \\
\hline \multirow{3}{*}{$\begin{array}{l}\text { Commitment } \\
\text { (CO) }\end{array}$} & $\mathrm{CO} 1$ & .8602 & \multirow{3}{*}{.8432} & \multirow{3}{*}{.6493} & \multirow{3}{*}{.7505} \\
\hline & $\mathrm{CO} 2$ & .9249 & & & \\
\hline & $\mathrm{CO} 3$ & .5937 & & & \\
\hline \multirow{3}{*}{ Trust (TR) } & TR1 & .5779 & \multirow{3}{*}{.7901} & \multirow{3}{*}{.5651} & \multirow{3}{*}{.7169} \\
\hline & TR2 & .7199 & & & \\
\hline & TR3 & .9183 & & & \\
\hline \multirow{3}{*}{$\begin{array}{l}\text { IT Infrastructure } \\
\text { (IT) }\end{array}$} & IT1 & .8696 & \multirow{3}{*}{.9094} & \multirow{3}{*}{.7699} & \multirow{3}{*}{.8430} \\
\hline & IT2 & .8658 & & & \\
\hline & IT3 & .8966 & & & \\
\hline \multirow{3}{*}{$\begin{array}{l}\text { Switching Costs } \\
\text { (SC) }\end{array}$} & SC1 & .8686 & \multirow{3}{*}{.8614} & \multirow{3}{*}{.6798} & \multirow{3}{*}{.8067} \\
\hline & SC2 & .6374 & & & \\
\hline & $\mathrm{SC} 3$ & .9374 & & & \\
\hline \multirow{2}{*}{$\begin{array}{c}\text { Willingness to OI } \\
(\mathrm{OI})\end{array}$} & OI1 & .9324 & \multirow{2}{*}{.9338} & \multirow{2}{*}{.8758} & \multirow{2}{*}{.8524} \\
\hline & OI2 & .9393 & & & \\
\hline
\end{tabular}

Note. * Average Variance Extracted 
(Chin 1998). Table 3 shows that our composite reliability values range from .7901 to .9338. As shown in Table 3, the AVE values range from .5651 to .8758 , which are above the acceptability (i.e., .5) (Fornell and Larcker 1981). Table 3 also reports factor loading values of the measures in our research model.

We also verified the discriminant validity of our instruments by looking at the square root of AVE as suggested by Fornell and Larcker (1981). The square root of AVE for each construct is greater than the levels of correlations involving the construct as reported in Table 4. The results of pairwise correlations also show that each construct shares larger variance with its own measures than with other measures. Table 4 also illustrates pairwise correlations between all the explanatory variables. The highest absolute value of pairwise correlation is .405, which is below the frequently-used threshold of .6 suggested by Nunally and Bernstein (1994) (See Table 4). Finally, we also calculated variance inflation factors (VIFs) to detect multicollinearity among the explanatory variables.
The highest VIF is 3.180, which is far below the threshold of 10 (Nunally and Bernstein 1994).

\section{Results}

\subsection{Hypotheses Testing}

With an adequate measurement model and an acceptable level of multicollinearity, we further examined the proposed hypotheses with PLS. The results of the analysis are summarized with path coefficients and $t$-values in Figure 2. Four among five proposed hypotheses are significant at the level of .05.

The result shows that firms' trust to their alliance partners has a significant positive effect on the commitment- increasing firms' trust will increase the commitment with partner, supporting Hypothesis 1 (see Figure 2 for the result). The result also indicates that firms with high level of trust to existing alliance partners are likely to build high commitment.

$\langle$ Table 4〉 Correlation between Constructs

\begin{tabular}{|c|c|c|c|c|c|}
\hline & CO & TR & IT & SC & OI \\
\hline CO & .806 & & & & \\
\hline$T R$ & .247 & .752 & & & \\
\hline$I T$ & .241 & .302 & .877 & & \\
\hline$S C$ & .293 & -.103 & -.405 & .825 & \\
\hline OI & -.148 & .494 & .413 & -.598 & .936 \\
\hline
\end{tabular}

Note. CO: Commitment; TR: Trust; IT: IT Infrastructure; SC: Switching costs; OI: Willingness to open innovation; The shared numbers in the diagonal row are square roots of the average variance extracted (AVE). 


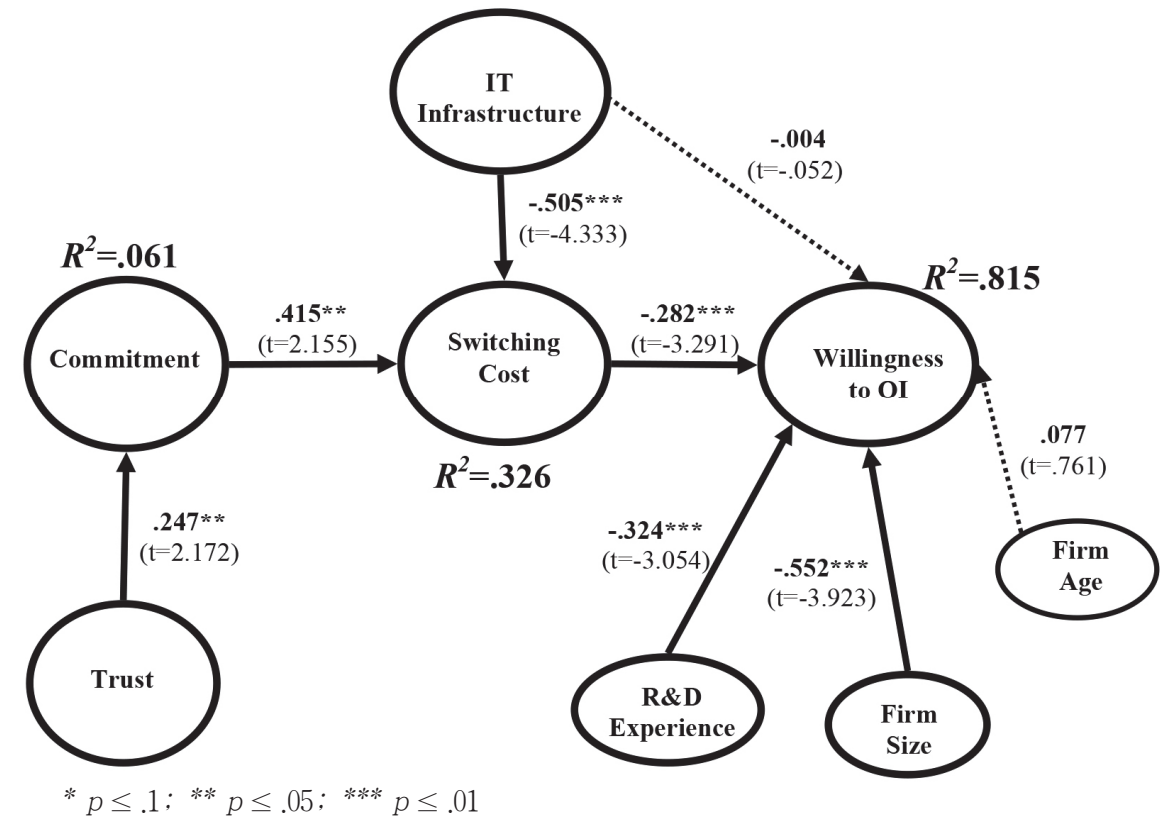

The positive and significant coefficient of commitment on switching costs also support Hypothesis 2-increasing firms' level of commitment will increase the switching costs to open innovation (see Figure 2 for the result). This result suggests that firms with high commitment would have high switching costs to discontinue their relationship.

As expected, a firm's IT infrastructure has significant negative effect on the switching costs, supporting Hypothesis 3 (see Figure 2 for the result). Inconsistent with Hypothesis 4 , however, a firm's IT infrastructure shows an insignificant effect on the adoption of open innovation. These results indicate that the level of IT infrastructure has an indirect, mediating effect on the adoption of open innovation through switching costs - that is, firms with a high level of IT infrastructure will need less switching costs to adopt the open innovation. The negative and significant coefficient of switching costs on willingness to participate in open innovation supports Hypothesis 5-an increase in switching costs will lead to a decrease in the willingness to participate in open innovation (see Figure 2 for the result). The result provides evidence that when firms expect high switching costs, they are less likely to participate in open innovation.

$R \& D$ alliance experience and firm size (i.e., the number of employees) were significant as control variables. The estimation results show that the number of $R \& D$ alliances and the number of employees have adverse effects on 
firms' willingness to participate in open innovation (see Figure 2 for the result).

As we discussed, we investigate if "switching costs" mediates the relationship between IT infrastructure and willingness to participate in open innovation and commitment and willingness to participate in open innovation. Although switching costs does mediate the relationship between commitment and willingness to participate in open innovation, we also find an indirect effect of trust on commitment. This indirect effect is mediated through commitment, and impacts on the willingness to participate in open innovation. In the model, switching costs is critical as a mediating variable that has direct influence on the willingness to participate in open innovation.

\subsection{Additional Analysis - Group Difference}

Firms with a high cooperation background tend to systematically cooperate with different partners at different levels. On the contrary, firms with a low cooperation background work almost in isolation. Therefore, the relationships with other partners are important in the innovation strategy.

To check the group differences, this research examines the relationship between the dependent variable and following demographic variables:

(1) the number of licensing, (2) work experience, (3) length of alliance, (4) the number of patents, and (5) the number of product developments. Table 4 summarizes the results of One-way ANOVA analyses.

The results show that the first three variables that represent the maturity of a company have adverse effects on firms' willingness to participate in the open innovation (see Table 5). A possible explanation is that the firm, given that it is quite mature, may already have a very strong commitment to existing research partners. One of the interesting findings in the analyses of the group differences is that the number of patents and the number of product developments show a u-shaped relationship with the dependent variable (see Table 5). Firms with few patents expect more benefits than risk-taking of their own knowledge in

〈Table 5〉 Summary of One-Way ANOVA Analysis

\begin{tabular}{|c|c|c|c|c|c|}
\hline \multirow{2}{*}{$\begin{array}{l}\text { Dependent } \\
\text { Variable }\end{array}$} & \multicolumn{5}{|c|}{ Demographic Variables } \\
\hline & $\begin{array}{l}\text { Number of } \\
\text { Licensing }\end{array}$ & $\begin{array}{c}\text { Work } \\
\text { Experience }\end{array}$ & $\begin{array}{c}\text { Alliance } \\
\text { Year }\end{array}$ & $\begin{array}{l}\text { Number of } \\
\text { Patents }\end{array}$ & $\begin{array}{c}\text { Number of } \\
\text { R\&D }\end{array}$ \\
\hline $\begin{array}{l}\text { Willingness to } \\
\text { Participation }\end{array}$ & 紫*** & 资档 & 类**** & $\mathrm{U}^{* *}$ & $\mathrm{U}^{* * *}$ \\
\hline
\end{tabular}

Note. Significance levels: * if $p<.10, * *$ if $p<.05, * * *$ if $p<.01$

* negative relationship, $U$ : $U$ shape relationship 
open knowledge sharing, and firms with many patents also feel little risk in open knowledge sharing because of abundant technical resources. However, firms with medium number of patents and R\&Ds hesitate to participate in the open innovation because they are reluctant to take a risk on their core technical know-how's.

This research also examines the effect of the respondent's role difference within the organization. The role difference-i.e., CEOs and CSOs may influence how efficiently and readily they recognize, assimilate, and apply new information and technologies to the benefits of the firm. Different insights and perspectives on the subject were gathered via interviews with CSOs, whose role in a firm is more related to developing technical knowledge. For the role difference, a dummy variable is used, with 1 for CEOs and 0 for CSOs. However, we find that the role difference has little effect in the model. This may result from the sampling practices - CEOs or CSOs of only small biotech firms were selected. Therefore, including big biotech firms and pharmaceutical firms in the sample and comparing the results will be useful in terms of some combined effects of role difference and the size of firms.

\section{Discussion and Conclusion}

In conclusion, we present the overall findings and implications of this research, consider some of its limitations, and identify a number of future directions for valuable interdisciplinary research on this topic that will yield new managerial knowledge about technology sharing in the open innovation.

\subsection{Research Findings}

The purpose of this study is to identify the factors which influence the willingness to participate in open innovation. We considered the willingness to participate in open innovation as switching from closed development to open development because in order to participate in the open innovation, firms have to terminate existing alliances or reduce the level of knowledge sharing with existing alliance partners. Therefore, in addition to commitment (based on the trust) with existing research partners, IT infrastructure within a firm and expected switching costs were tested against the prospects of open innovation.

We find that commitment has positive effects on firms' switching costs, while IT infrastructure has negative effects on firms' switching costs. Firms, having strong trust with existing alliance partners, show strong commitment with existing alliance relationships. Firms, if the switching costs entailed are too high, will protect the knowledge exposure in open innovation. Based on our research findings, we think, the major contribution of this study is to investigate why 
and why not firms participate in open innovation. To effectively leverage open innovation as a new manner of innovation, leading firms into open innovation is the most fundamental step. However, extant literature has mainly focused on examining the overall effect of open innovation on firm performance or new product development through open innovation. This study makes a substantial contribution by examining the factors that influence the willingness to participate in open innovation from ongoing closed alliances.

From the group difference check, open innovation tends to be appreciated by firms with less licensing, firms with less alliance experience, and less experienced managers. This is because (1) firms that are highly committed to existing research partners want to keep their research partners; (2) comparatively firms with more alliance have better resources and/or have established a long-term relationship with their research partners. The number of patents and the number of product developments show a $u$-shaped relation with the willingness to participate in open innovation (see Table 5). It may be asked: how many patents will be perceived as risky to be open in the virtual laboratory and how many product developments will lead firms to participate in open innovation? This research also examined the role difference of CEOs and CSOs to check if there is any effect of role difference on firms' attitudes toward knowledge transfer through open innovation. The role difference does not appear to have significant effects.

\subsection{Research Implications}

The findings in this study provide valuable insights for the following questions - (1) why or why not firms participate in open innovation, (2) what should be done to lead firms into open innovation, and (3) what should be taken into account for successful adoption of open innovation. For virtual laboratory operators in biotech firms, in particular, establishing a good relationship with partners or potential partners should not be overlooked. This is because the firms' decision about whether or not to form other alliances through open innovation will be affected to a considerable extent by the states of their current relationship.

This research also broadens the study of open innovation by introducing the role of virtual laboratory in the exchange of knowledge. Although innovation is undergoing a paradigm shift from 'closed' to 'open' models, at present, biotech companies hesitate to participate in the online virtual laboratory as a tool of open innovation. The findings provide valuable insights for biotech firms because this study can shed light on what went wrong and what they should have taken into account for success of their virtual laboratory. This study also points out the way for further research that will enhance our understanding of how knowledge is interpreted to firms under open innovation 
and thus provides the basis for a more complete understanding of knowledge transfer in open innovation.

\subsection{Limitation and Future Research}

There are several limitations in this research deserving of further discussion. First, our sampling pool is restricted to mainly small and young biotech firms - so, results of the study might be biased given the size and youth of the firms. We believe that examining firms with a more diverse maturity or background will enable us to construct and validate more generalized model. Second, due to the difficulties of getting firm-level data in a specific industry, the sample size we had is small. So, the sample size certainly limits the test of discriminant validity and construct validity. Third, the use of data from the UK biotech firms may lead to difficulties in generalizing our findings. In future research, the use of the US or Asian firm data and the comparison of results across countries are also suggested. Finally, the research model of this study includes relationship-related factors (e.g., trust, commitment, switching cost) and IT-related factor (e.g., It infrastructure). This study, however, does not consider firms' knowledgeor resource-related factors (e.g., knowledge redundancy, knowledge stock), which could be the critical factors affecting open innovation adoption.

The following are some other suggestions for future research: (1) to extend data to pharmaceutical firms and compare the prospects of open innovation in biotech and larger main stream pharmaceutical firms; (2) to compare firms' attitudes toward open innovation at different stages of drug development because of varying technological risks in each stage of drug development; and (3) to include more variables such as power exercised and technology opportunism to explain open innovation.

〈Received December 4. 2017〉

〈Accepted January 28. 2018〉

\section{References}

Almirall, E., \& Casadesus-Masanell, R. (2010). Open versus closed innovation: A model of discovery and divergence. Academy of Management Review, 35(1), 27-47.

Anderson, E., \& Weitz, B. (1989). Determinants of continuity in conventional industrial channel dyads. Marketing Science, 8(4), 310-323.

Anderson, E., \& Weitz, B. (1992). The use of pledges to build and sustain commitment in distribution channels. Journal of Marketing Research, 29(1), 18-34.

Angle, H. L., \& Perry, J. L. (1981). An empirical assessment of organizational commitment and organizational effectiveness. Administrative Science Quarterly, 26(1), 1-14. 
Atuahene-Gima, K., \& Evangelista, F. (2000). Cross-functional influence in new product development: An exploratory study of marketing and R\&D perspectives. Management Science, 46(10), 1269-1284.

Bharadwaj, A. (2000). A resource-based perspective on information technology capability and firm performance: An empirical investigation. MIS Quarterly, 24(1), 169-196.

Boudreau, K. (2010). Open platform strategies and innovation: Granting access vs. devolving control. Management Science, 56(10), 18491872.

Boudreau, M.-C., Loch, K. D., Robey, D., \& Straub, D. (1998). Going global: Using information technology to advance the competitiveness of the virtual transnational organization. Academy of Management Executive, 12(4), 120-128.

Boynton, A. C., Zmud, R. W., \& Jacobs, G. C. (1994). The IT management practice on IT use in large organizations. MIS Quarterly, 18(3), 299-318.

Cavusgil, T. S., Calantone, R. J., \& Zhao, Y. (2003). Tacit knowledge transfer and firm innovation capability. Journal of Business and Industrial Marketing, 18(1), 6-21.

Ceccagnoli, M., Graham, S. J. H., Higgins, M. J., \& Lee, J. (2010). Productivity and the role of complementary assets in firms' demand for technology innovations. Industrial and Corporate Change, 19(3), 839-869.

Chen, P., \& Forman, C. (2006). Can vendors influence switching costs and compatibility in an environment with open standards? MIS Quarterly, 30(Special Issue), 541-562. Chesbrough, H. W. (2003). Open Innovation: The New Imperative for Creating and Profiting from Technology, Harvard Business School Press, Boston, MA.

Chesbrough, H., \& Crowther, A. K. (2006). Beyond high tech: Early adopters of open innovation in other industries. $R \& D$ Management, 36(3), 229-236.

Chin, W. W. (1998). The partial least squares approach to structural equation modelling. in Marcoulides, G. A. (Eds.), Modern Methods for Business Research, Lawrence Erlbaum Associates, Mahwah, NJ, 295-336. Christensen, J. F., Olesen, M. H., \& Kjær, J. S. (2005). The industrial dynamics of open innovation - evidence from the transformation of consumer electronics. Research Policy, 34(10), 1533-1549.

Cohen, W. M., \& Levinthal, D. A. (1990). Absorptive capacity: A new perspective on learning and innovation. Administrative Science Quarterly, 35(1), 128-152.

Dahlander, L., \& Gann, D. M. (2010). How open is innovation. Research Policy, 39(6), 699-709.

Das, T. K., \& Teng, B.-S. (2002). Alliance constellations: A social exchange perspective. Academy of Management Review, 27(3), 445-456.

Doney, P. M. \& Cannon, J. P. (1997). An 
examination of the nature of trust in buyer-seller relationships. Journal of Marketing, 61(2), 35-51.

Doz, Y. L. \& Hamel, G. (1998). Alliance Advantage, Harvard Business School Press, Boston, MA.

Dwyer, F. R., Schurr, P. H., \& Oh, S. (1987). Developing buyer-seller relationships. Journal of Marketing. 51(2), 11-27.

Ebner, W., Leimeister, J. M., \& Kromar, H. (2009). Community engineering for innovations: The ideas competition as a method to nurture a virtual community for innovations. R\&D Management, 39(4), 342-356.

Fabrizio, K. R. (2009). Absorptive capacity and the search for innovation. Research Policy, 38(2), 255-267.

Fishbein, M., \& Ajzen, I. (1975). Beliefs, Attitude, Intention and Behaviour: An Introduction to Theory and Research, Addison-Wesley Publishing Company, Reading, MA.

Fornell, C., \& Bookstein, F. L. (1982). Two structural equation models: LISREL and PLS applied to consumer exit-voice theory. Journal of Marketing Research, 19(4), 440452.

Fornell, C., \& Larcker, D. F. (1981). Structural equation models with unobservable variables and measurement errors. Journal of Marketing Research, 18(2), 39-50.

Füller, J., Matzler, K., \& Hoppe, M. (2008). Brand community members as a source of innovation. Journal of Product Innovation
Management, 25(6), 608-619.

Ganesan, S. (1994). Determinants of long-term orientation in buyer-seller relationships. Journal of Marketing, 58(2), 1-19.

Grimpe, C., \& Sofka, W. (2009). Search patterns and absorptive capacity: Low- and hightechnology sectors in European countries. Research Policy, 38(3), 495-506.

Gulati, R., \& Singh, H. (1998). The architecture of cooperation: Managing coordination costs and appropriation concerns in strategic alliances. Administrative Science Quarterly, 43(4), 781-814.

Hair, J. F., Anderson, R. E., Tatham, R. L., \& Black, W. C. (1998). Multivariate Data Analysis with Readings, $5^{\text {th }}$ ed., Prentice Hall, New York, NY.

Heide, J. B., \& Weiss, A. M. (1995). Vendor consideration and switching behaviour for buyers in high-technology markets. Journal of Marketing, 59(3), 30-43.

Hult, G. T. M., Kerchen, D. J., \& Slater, S. F. (2002). A longitudinal study of the learning climate and cycle time in supply chains. Journal of Business and Industrial Marketing, 17(4), 302-323.

Ili, S., Albers, A., \& Miller, S. (2010). Open innovation in the automotive industry. R\&D Management, 40(3), 246-255.

Jarvenpaa, S. L., Shaw, T. R., \& Staples, D. S. (2004). Toward contextualized theories of trust: The role of trust in global virtual teams. Information Systems Research, 15 
(3), 250-267.

Kankanhalli, A., Tan, B. C. Y., \& Wei, K.-K. (2005). Contributing knowledge to electronic knowledge repositories: An empirical investigation. MIS Quarterly, 29(1), 113143.

Kelly, H., \& Thibaut, J. W., (1978). Interpersonal Relations: A Theory of Interdependence, Wiley, New York, NY.

Kim, K., Kim, J., Min, J., \& Ryu. S. (2017). How network structure impacts firm performance. Asia Marketing Journal, 19 (1), 19-34.

Kim, J., \& Wilemon, D. (2014). Organizational learning as catalyst to technological innovation. Asia Marketing Journal, 16(3), $35-56$.

Koch, J. L., \& Steers, R. M. (1978). Job attachment, satisfaction, and turnover among public sector employees. Journal of Vocational Behaviour, 12(1), 119-128.

Kogut, B. (1988). Joint ventures: Theoretical and empirical perspectives. Strategic Management Journal, 9(4), 319-332.

Kohler, T., Matzler, K., Füller, J. (2009). Avatarbased innovation: Using virtual worlds for real-world innovation. Technovation, 29(6 - 7), 395-407.

Lau, A. K. W., Tang, E., \& Yam, R. C. M. (2010). Effects of supplier and customer integration on product innovation and performance: Empirical evidence in Hong Kong manufacturers. Journal of Product
Innovation Management, 27(5), 761-77.

Mangalam, H., Stewart, J., Zhou, J., Schlauch, K., Waugh, M., Chen, G., Farmer, A.D., Colello, G., \& Weller, J. W. (2001). GeneX: An open source gene expression database and integrated tool set. IBM Systems Journal, 40(2), 552-569.

Moorman, C., Zaltman, G., \& Deshpande, R. (1992). Relationships between providers and users of market research: The dynamics of trust within and between organizations. Journal of Marketing Research, 29(3), 314-328.

Morgan, R. M., \& Hunt, S. D. (1994). The commitment-trust theory of relationship marketing. Journal of Marketing, 58(3), 20-38.

Newell. S., \& Swan, J. (2000). Trust and interorganizational networking. Human Relations, 53(10), 1287-1328.

Newman, M. \& Sabherwal, R. (1996). Determinants of commitment to information systems development: A longitudinal investigation. MIS Quarterly, 20(1), 23-54.

Nunnally, J. C., \& Bernstein, I. H. (1994). Psychometric Theory, $3^{\text {rd }}$ ed., McGrawHill, New York, NY.

Osborn, C. S., Madnick, S. E., \& Wang, Y. R. (1990). Motivating strategic alliance for composite information systems: The case of a major regional hospital. Journal of Management Information Systems, 6(3), 99-117. 
Pavlou, P. A., \& El Sway, O. A. (2006). From IT leveraging competence to competitive advantage in turbulent environments: The case of new product development. Information Systems Research, 17(3), 198-227.

Porter, L. W., Steers, R. M., Mowday, R. T., \& Boulian, P. V. (1974). Organizational commitment, job satisfaction, and turnover among psychiatric technicians. Journal of Applied Psychology, 59(5), 603-609.

Powell, W. W. (1998). Learning from collaboration: Knowledge and networks in the biotechnology and pharmaceutical industries. California Management Review, 40(3), 228-240.

Premkumar, G., \& Ramamurthy, K. (1995). The role of interorganizational and organizational factors on the decision mode for adoption of interorganizational systems. Decision Sciences, 26(3), 303-333.

Ring, P., \& Van de Ven, A. (1994). Developmental processes of cooperative interorganizational relationships. Academy of Management Review, 19(1), 90-118.

Roberts, J. A., Hann, I.-H., \& Salughter, S. A. (2006). Understanding the motivations, participation, and performance of open source software developers: A longitudinal study of the apache projects. Management Science, 52(7), 984-999.

Rogers, E. M. (1995). Diffusion of Innovation, The Free Press, New York, NY.

Ross, J. W., Beath, C. M., \& Goodhue, D. L. (1996). Develop long-term competitiveness through IT assets. Sloan Management Review, 38(1), 31-45.

Sambamurthy, V., Bharadwaj, A., \& Grover, V. (2003). Shaping agility through digital options: Reconceptualizing the role of IT in contemporary firms. MIS Quarterly, 27 (2), 237-263.

Schiele, H. (2010). Early supplier integration: The dual role of purchasing in new product development. R\&D Management, 40(2), 138-53.

Schurr, P. H. \& Ozanne, J. L. (1985). Influences on exchange processes: Buyers' preconceptions of a seller's trustworthiness and bargaining toughness. Journal of Consumer Research, 11(4), 939-953.

Staropoli, C. (1998). Cooperation in R\&D in the pharmaceutical industry - the network as an organizational innovation governing technological innovation. Technovation, 18 (1), 13-23.

Stewart, K. J., \& Gosain, V. (2006). The Impact of Ideology on Effectiveness in Open Source Software Development Teams. MIS Quarterly, 30(2), 291-314.

Teirlinck, P., Dumont, M., \& Spithoven, A. (2010). Corporate decision-making in R\&D outsourcing and the impact on internal R\&D employment intensity. Industrial and Corporate Change, 19(6), 1741-1768.

Tether, B. S., \& Tajar., A. (2008). Beyond industry-university links: Sourcing knowledge for innovation from consultants, private 
research organisations, and the public science-base. Research Policy, 37(6-7), 1079-95.

Un, C.A., Cuervo-Cazurra, A., \& Asakawa, K. (2010). R\&D collaborations and product innovation. Journal of Product Innovation Management, 27(5), 673-689.

von Krogh, G., \& von Hippel, E. (2006). The promise of research on open source software. Management Science, 52(7), 975-983.

Wasko, M. M., \& Faraj, S. (2005). Why should I share? Examining social capital and knowledge contribution in electronic networks of practice. MIS Quarterly, 29(1),
35-57.

Weill, P., Broadbent, M. (1998). Leveraging the New Infrastructure: How Market Leaders Capitalize on Information Technology, Harvard Business School Press, Cambridge, MA. Weiss, A. M., \& Anderson, E. (1992). Converting from independent to employee salesforce: The role of perceived switching costs. Journal of Marketing Research, 29(1), 101-115.

Wilson, D. T. (1995). An integrated model of buyer-seller relationships. Journal of the Academy of Marketing Science, 23(4), $335-345$. 